\title{
Sentrin-Specific Protease 6
}

National Cancer Institute

\section{Source}

National Cancer Institute. Sentrin-Specific Protease 6. NCI Thesaurus. Code C98049.

Sentrin-specific protease 6 (1112 aa, $126 \mathrm{kDa})$ is encoded by the human SENP6 gene.

This protein is involved in desumoylation of proteins. 